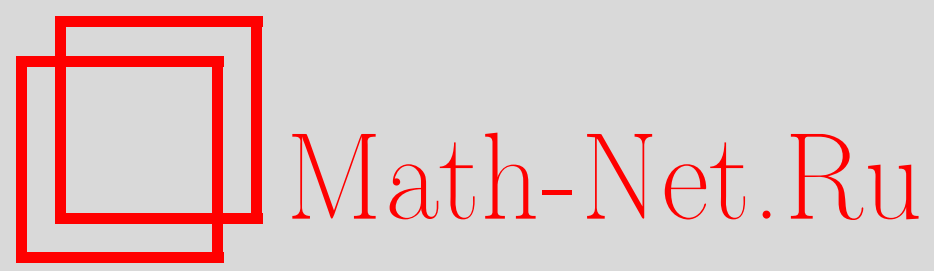

S. M. Darya zadeh, G. I. Lvov, Stress analysis in an infinite hydroxyapatite/titanium plate with a pressurized circular hole, Vestn. Udmurtsk. Univ. Mat. Mekh. Komp. Nauki, 2015, Volume 25, Issue 2, 267-279

Use of the all-Russian mathematical portal Math-Net.Ru implies that you have read and agreed to these terms of use

http: //www. mathnet.ru/eng/agreement

Download details:

IP : 3.85 .73 .92

April 26, 2023, 12:17:26 
MSC: $73 \mathrm{C}$

\author{
(C) S. Darya zadeh, G.I. Lvov
}

\title{
STRESS ANALYSIS IN AN INFINITE HYDROXYAPATITE / TITANIUM PLATE WITH A PRESSURIZED CIRCULAR HOLE
}

The aim of the present study is to compute the macro- and microstress concentration in a reinforced biomaterial composite plate with a circular hole with respect to the volume ratio of the component materials in the composite. The contour of the circular hole and its dependency on the structure of a plate were calculated in order to study the behaviors of macro- and microstresses. In this paper, the stress around a circular hole was calculated for an orthotropic unidirectionally fiber-reinforced plate with respect to the volume ratio of the component materials in the composite. Stress distribution using a theoretical method and the finite elements method was calculated. The boundary conditions applied on the contour of a circular hole are uniform normal pressure. In this present study, we use a new numerical method of determining microstresses for composite plates with a circular hole, on the boundary of which there is a uniform normal pressure. The results demonstrate the macro- and microstresses calculated for two different structures and the behavior of an orthotropic plate with a circular hole. The ANSYS package and the finite-element representative plate model were used in this study.

Keywords: composite, unidirectional fibers, numerical method, boundary conditions, stress concentration.

\section{Introduction}

Materials that are used for biomedical or clinical applications are known as biomaterials. The following article deals with fifth generation of biomaterials that are used for bone structure replacement. The biomaterial term is used for materials that can be used in biomedical and clinical applications. They are bioactive and biocompatible in nature. Currently, many types of metals and alloys, ceramics and polymers are used for load bearing application. This includes dental replacement and bone joining or replacement for medical and clinical application. Therefore their mechanical properties are very important [1]. The bioactive and biodegradable properties of hydroxyapatite make this material a preferred candidate for implants such as bone replacement in replacing natural tissues damaged by diseases and accidents [1-8]. However, it has lower young's modulus and fracture toughness with brittle nature. Hence, it is required to produce a biomaterial with good mechanical properties. The study of strength of materials is often research on elastoplastic and failure behavior in parts and structures. Many artificial body parts with a hole (or any number of holes) are used for structural applications in medicine. For example, the cranial repair plates with holes for bolted locations, the bolted connections are designed to hold two or more parts together to form an assembly in the body. Because of different loading conditions on the boundary of hole, especially high loads, one can create stress concentration (for instance $[9,10]$ ).

Unidirectionally fiber-reinforced composite plates are widely used for structural applications where high strength-to-weight ratio is required. In these plates making holes or cut outs are avoidable for various purposes. Holes in composites will create stress concentration and hence will reduce the mechanical properties. The prediction of reduction in the mechanical properties caused by holes is very important for composite designers.

The stress concentration behavior of pin-loaded holes and problems for calculation of minimum distance between holes in composite plates are always one of the important issues in solid mechanics. The solution of the elastic plate theory by the complex functions provides the solution of isotropic and anisotropic plates with holes. The use of complex variables was first introduced by Muskhelishvili (1963) [11]. The functions used for the problems will satisfy the desired boundary conditions. 
The purpose of this research is to compute the stress concentration around the hole in a composite plate based on the theory of elasticity of anisotropic materials by the application of complex functions (Lekhnitskii S. (1968) and Savin G. (1961) [12, 13]). Through this method and the boundary conditions of normal pressure distributed, the stress concentration is calculated around the hole in orthotropic plates.

The study will be using complex functions to determine the effective elastic coefficients of the plates as presented by Vanin [14]. Subsequently, the stress around a circular hole in an orthotropic unidirectionally fiber-reinforced plate is calculated with respect to the volume ratio of the component materials in composite.

Numerical methods for calculating the composite material properties typically involve analysis of a representative volume element and a great number of micromechanical models that have been proposed for predicting various mechanical properties of composite materials [15-19]. For describing the behavior of elastic unidirectional composites, a great number of mathematical models are known [20-27]. In this work, the results of the numerical calculations were presented for total stress concentration in the orthotropic plate for square and hexagonal structures with respect to the volume ratio of the component materials in the composites.

In this report, the finite element method was used to approximate the different elastic properties of the fiber-reinforced composites. A theoretical method and ANSYS (ANSYS, Ver. 11, [NTU "KhPI" company EMT U, Kiev, 2010]) was used to calculate the results of the numerical stress distribution.

\section{$\S 1$. Determining the effective elasticity constants in composite plates}

The composite plate consists of two phases in the matrix-reinforcement plane. In this platen, it is assumed that the reinforcement fiber is placed along the axle $x$ in the plate. The determination of the effective elasticity coefficients of the orthotropic plate by knowledge of the mechanical properties of the matrix and reinforcement by mixed functions was proposed by G. Vanin. In formulas (1) $E_{1}, E_{2}, G_{12}, v_{12}$ are the modulus of elasticity (Young's modulus), shear modulus and Poisson's ratio of the plate, respectively. $E, G, v$ are modulus of elasticity, shear modulus and Poisson's ratio of the matrix and reinforcement, respectively. The subscripts $m$ and $\alpha$ denote the matrix and the reinforcement, respectively. It is assumed that the location of the main axis fibers is along the $x$-axis. The following formulas determine the effective elastic constants of the plate based on the mechanical properties of the constituent phases and the volume ratio of the component materials in the composite [14].

$$
\begin{gathered}
E_{1}=\xi E_{a}+(1-\xi) E_{m}+\frac{8 G_{m} \xi(1-\xi)\left(v_{a}-v_{m}\right)}{2-\xi+\chi_{m} \xi+(1-\xi)\left(\chi_{a}-1\right) \cdot G_{m} / G_{a}} ; \\
G_{12}=G_{m} \frac{1-\xi+(1-\xi) \cdot G_{m} / G_{a}}{1-\xi+(1+\xi) \cdot G_{m} / G_{a}} ; \quad v_{21}=v_{m}-\frac{\left(\chi_{m}+1\right)\left(v_{m}-v_{a}\right) \xi}{2-\xi+\chi_{m} \xi+(1-\xi)\left(\chi_{a}-1\right) \cdot G_{m} / G_{a}} ; \\
\frac{1}{E_{2}}=\frac{v_{21}^{2}}{E_{1}}+\frac{1}{8 G_{m}}\left[\frac{2(1-\xi)\left(\chi_{m}-1\right)+\left(\chi_{a}-1\right)\left(\chi_{m}-1+2 \xi\right) \cdot G_{m} / G_{a}}{2-\xi+\chi_{m} \xi+(1-\xi)\left(\chi_{b}-1\right) \cdot G_{m} / G_{a}}\right]+J
\end{gathered}
$$

Equivalency of:

$$
v_{12}=v_{21} \frac{E_{2}}{E_{1}}
$$

where $\chi=3-4 v$ and

$$
J=2 \frac{\chi_{m}(1-\xi)+\left(1+\xi \chi_{m}\right) \cdot G_{m} / G_{a}}{\chi_{m}+\xi+(1-\xi) \cdot G_{m} / G_{a}} .
$$

In the above equations, effective elasticity coefficients of the plate were dependent upon the volume ratio of the component (fiber). This ratio is dependent upon the placement manner and the distance between two reinforcement centers and is given by:

$$
\xi=\frac{\pi \cdot a^{2}}{w_{1}^{2} \cdot b \cdot \sin \alpha} .
$$


Here $\alpha$ is the radius of the reinforcement $0<\alpha<\pi / 2$ and $b>0$.

The longitudinal and transverse distance between two reinforcements is equal to $w_{1}$ and $w_{2}=w_{1} b e^{i \alpha}$, respectively. The present work is based on the volumetric occupancy coefficient in square and hexagonal arrangements [14].

Table 1 shows the relationships between the different values of volume ratio of components and the distance between the two reinforcement in the square $(\alpha=\pi / 2)$ and hexagonal $(\alpha=\pi / 3)$ arrangements for $b=1$.

Table 1. The relationship of the distance between the two reinforcement and volume ratios of the components

\begin{tabular}{|l|l|l|l|l|l|l|}
\hline \multirow{2}{*}{} & \multirow{2}{*}{ array } & \multicolumn{4}{|l|}{$w_{1}$} & \multicolumn{5}{|l|}{} \\
\cline { 3 - 7 } & & $2 a$ & $2.5 a$ & $4 a$ & $5 a$ & $8 a$ \\
\hline$\xi$ & square & 0.78 & 0.488 & 0.196 & 0.1225 & 0.049 \\
\cline { 2 - 7 } & hexagonal & 0.92 & 0.573 & 0.227 & 0.142 & 0.0574 \\
\hline
\end{tabular}

Among them hydroxyapatite and titanium are most widely studied bioactive and biocompatible material [1]. For numerical calculations, one type of composite plates were examined including; hydroxyapatite fiber plate with titanium fibers.

Table 2 classifies the mechanical properties of the matrix and reinforcing fiber of plate considering the reinforcement to the matrix shear modulus ratio of the composite plate.

Table 2. The mechanical properties of the matrix and reinforcement of the composite plate

\begin{tabular}{|l|l|l|l|}
\hline Materials: & $\mathrm{E}(\mathrm{MPa})$ & $G(\mathrm{MPa})$ & $v$ \\
\hline hydroxyapatite & 100000 & 38460 & 0.31 \\
\hline titanium & 102700 & 38180 & 0.345 \\
\hline
\end{tabular}

The effective elastic coefficients for square orthotropic plate are calculated using formulas (1), (2) and (3) for $w_{1}=2.5 a, b=1$ and $\xi=0.488$ by Maple. Table 3 shows the results.

Table 3. Mechanical characteristics of the orthotropic plate when $w_{1}=2.5 a, b=1$ and $\xi=0.488$

\begin{tabular}{|l|l|l|l|l|}
\hline Material & $\begin{array}{l}E_{1} \\
(\mathrm{MPa})\end{array}$ & $\begin{array}{l}E_{2} \\
(\mathrm{MPa})\end{array}$ & $\begin{array}{l}G_{12} \\
(\mathrm{MPa})\end{array}$ & $v_{12}$ \\
\hline $\begin{array}{l}\text { hydroxyapatite/titanium } \\
\text { composite }\end{array}$ & 102594 & 107877 & 38323 & 0.346 \\
\hline
\end{tabular}

\section{$\S 2$. Stress distribution in infinite orthotropic plate with one circular hole during the uniform normal pressure on hole border}

Consider a composite infinite plate with a circular hole. The polar system coordinate is in the center and point $o$ and $\theta$ angle is assumed to be on axle $x$. Uniform vertical pressure $P$ is applied on boundary the hole (Fig. 1).

The unidirectionally reinforcing fibers in an orthotropic plate are aligned unidirectional. It is assumed that the main axis of elasticity is the $x$-axis. The stress concentration in anisotropic plates with holes was first calculated by Lekhnitskii (1968) using complex functions. Lekhnitskii presented the solution method and related formulas. For easy of use and simplification of formulas, the following relationships are used [3]:

$$
\begin{gathered}
m=\frac{E_{1}}{G_{12}}-2 v_{12} ; \quad k=\sqrt{\frac{E_{1}}{E_{2}}} ; \quad n=\sqrt{2 k+m} ; \\
\frac{1}{E_{\theta}}=\frac{\sin ^{4} \theta}{E_{1}}+\left(\frac{1}{G_{12}}-\frac{2 v_{12}}{E_{1}}\right) \sin ^{2} \theta \cos ^{2} \theta+\frac{\sin ^{4} \theta}{E_{2}} .
\end{gathered}
$$

$E_{\theta}$ is Young module for tangent (shear) direction. 


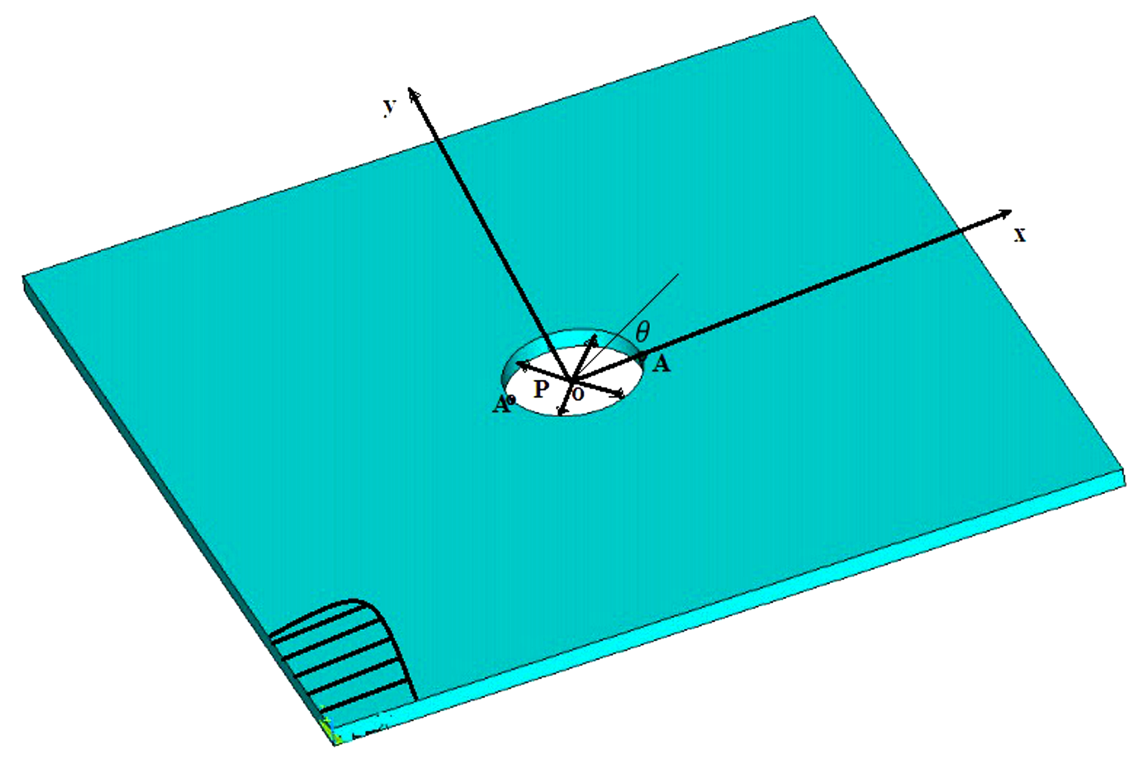

Figure 1. The unidirectional reinforcement plate with a pressurized circular hole

The parameters $E_{1}$ and $E_{2}$ are Young's modules of elasticity for the principal axis; $v_{12}$ and $G_{12}$ are the Poisson's ratio and the shear modulus on xoy plate respectively, as obtained from the formula (5); $E_{1}$ is the Young's modulus for the main direction on the $x$-axis.

In this document, the problem is studied in linear elasticity mode and the problem is solved for the plate by applying a uniform pressure $P$ on the contour of a circular hole.

Uniform normal pressure $P$ on a unit area of the plate is considered. The pressure is normally distributed on the contour of the circular hole. Lekhnitskii provided an expression for circumferential stress around of the circular hole as follows [3]:

$$
\sigma_{\theta}=P f_{\theta}
$$

where $f_{(\theta)}=\frac{E_{\theta}}{E_{1}}\left\{n-k+n(k-1) \cos ^{2} \theta+\left[(k+1)^{2}-n^{2}\right] \sin ^{2} \theta \cos ^{2} \theta\right\}$ is non-dimensional function of the angle $\theta$ measured from the $x$-axis.

The ratio of the circumferential stress to the force $P$ around the circular hole is

$$
K=\frac{\sigma_{\theta}}{P}
$$

where $\sigma_{\theta}$ is circumferential stress and the coordinate $\theta$ is evaluated based on axle $x$.

In the case of a uniform normal pressure $P$ on the edge of the composite plate, the stress concentration at point $A$ is (Fig. 2):

$$
K_{(\text {Micro })}=\frac{\sigma_{\theta(\operatorname{Max})}}{P} .
$$

The change of $\sigma_{\theta} / P$ on hole edge with respect to angle $\theta$ around circular hole was calculated using Maple, given the characteristics listed in Table 1 for composite plate with square arrangement for $\xi=0.488$. Figure 2 demonstrates the change of square arrangement in the range of $\theta=0-90$. The maximum value of $\sigma_{\theta} / P$ will be at point $A$ around of circular hole where $\theta=0$ or 180 .

The stress concentration value around the edge of circular hole in the orthotropic plate with a circular hole was calculated by theory and software methods. The mechanical characteristics of the matrix and reinforcement are shown in Table 2. Square and hexagonal arrays of the plate were also evaluated in this study. The distance between the plate reinforcement center and the volume ratio of the component in square and hexagonal arrays are demonstrated in Table 1 . The results 


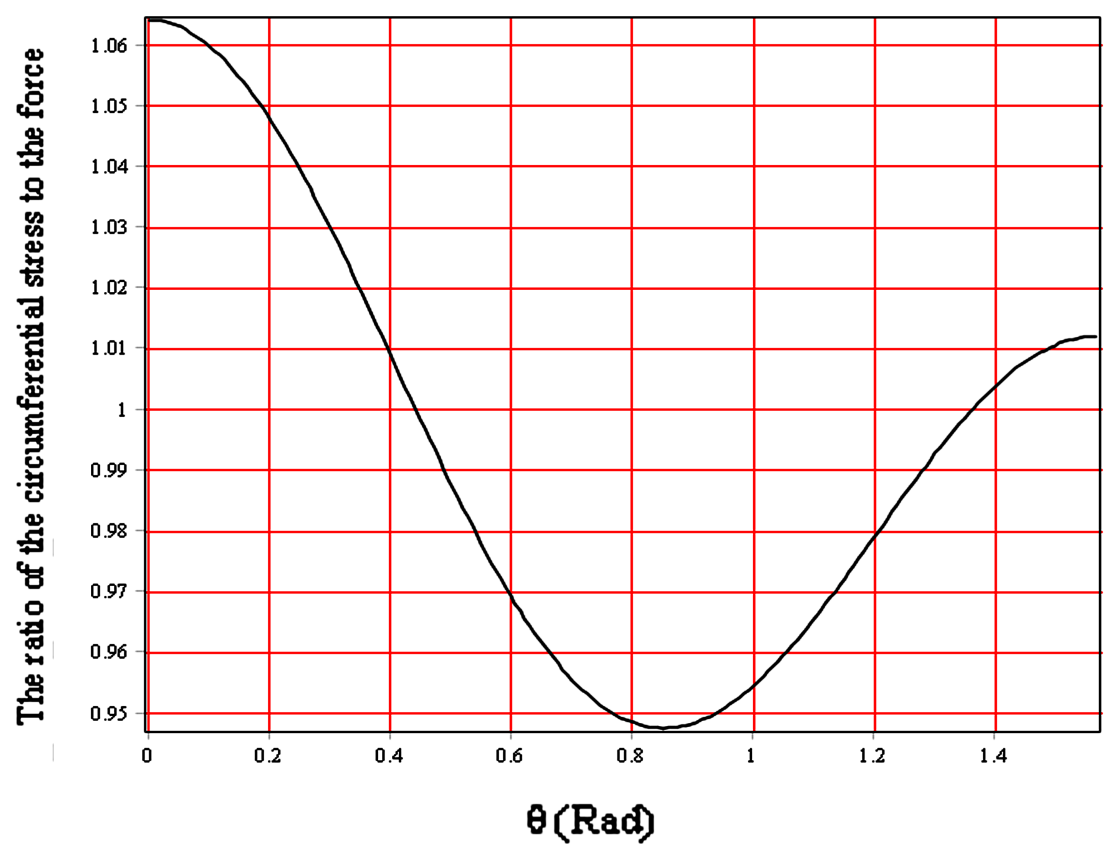

Figure 2. The change of $\sigma_{\theta} / P$ around the hole in the range of $\theta=0-90$

of this study were based on the stress concentration in the orthotropic composite plate due to the application of uniform normal pressure on the hole border. For numerical calculations, the normal pressure was applied on the hole border and the stress concentration value was calculated for various values of volume ratio of the component in the square and hexagonal arrays.

Figure 3 shows the stress concentration around the circular hole versus of radius $a$ for $b=1$ in the case of uniform normal pressure on the contour of the hole by the finite elements method. In the present paper, two charts 1,2 are given for the square and the hexagonal arrangement orthotropic plate.

\section{$\S 3$. Microstress concentration while applying uniform normal pressure on the boundary of a circular hole in an orthotropic plate: Finite Element Modeling}

The stress concentration exerted on the reinforcements, microstress concentration will be examined and the results will be discussed. The internal structure of the composite plate were considered and the cells were examined additionally, the microstress concentration was dependent on the stress concentration appeared around the circular hole (macrostress concentration). The microstress concentrations in the orthotropic plates were calculated under the boundary conditions [5], [8-12]. In this section, the finite element modeling and analysis of a composite plate with a circular hole for unidirectional fibers using ANSYS is discussed.

The plate was meshed with PLANE 2 element with four nodes and two degrees of freedom per node in two directions by 5641 elements $[4,5]$. Because of the symmetry for this solution, only quarter of models or cell models are considered and illustrated in Fig. 4 [10].

A regular two-dimensional arrangement of fiber in a matrix was adequate to describe the overall behavior of the composite, and was modeled as a regular uniform arrangement, as illustrated in Fig. 5. This model assumed that the fiber was a perfect cylinder of radius 0.79 , in a square $(1,1)$ for the square array and for a hexagonal $(1, \sqrt{3})$ of the matrix. It is assumed that the geometry, material and loading of the unit cell are symmetrical with respect to $y-z$ coordinate system as shown in Fig. 5. Therefore, $48.8 \%$ volume fraction fibers were inserted into the square matrix uniformly.

The microstress concentrations were calculated while distributing normal pressure $P$ on the boundary of the circular hole. The results indicated that the stress concentration caused by stress, $\sigma_{\theta(\operatorname{Max})}$ near hole would be at point $A$, the axis is assumed on the point $A$ (Fig. 1). 


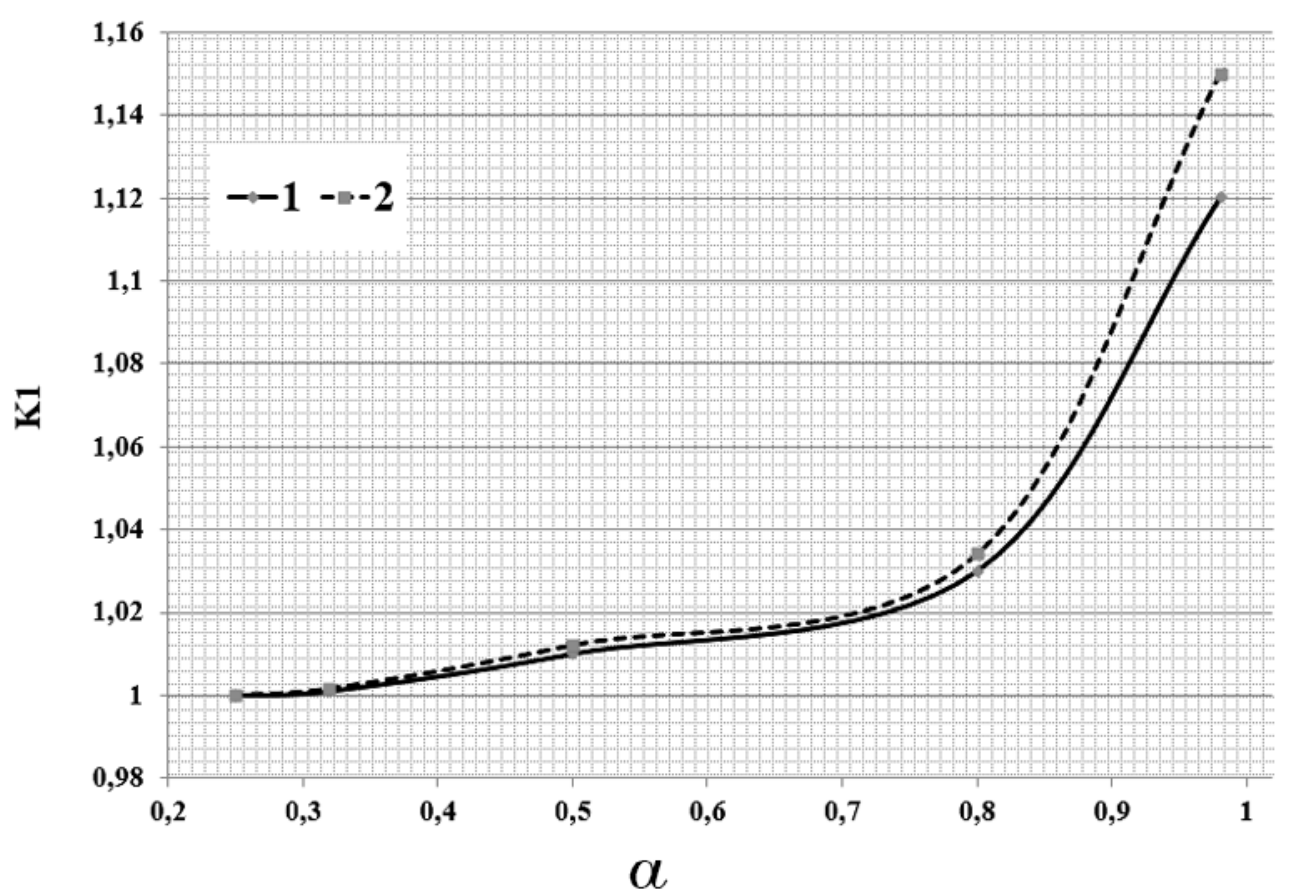

Figure 3. Stress concentration around the hole as a function of radius $a$

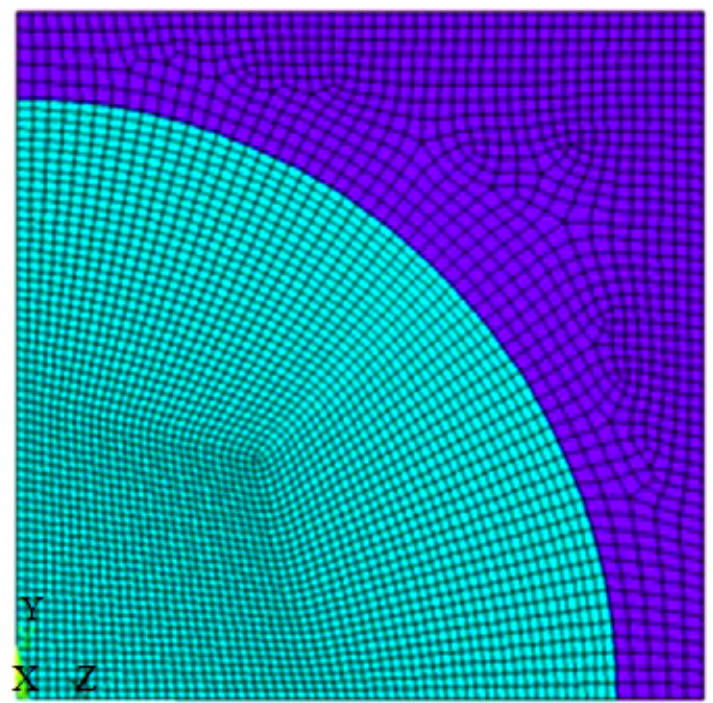

N

Figure 4. The quarter of model for an embedded cell meshed with PLANE 2 finite element 

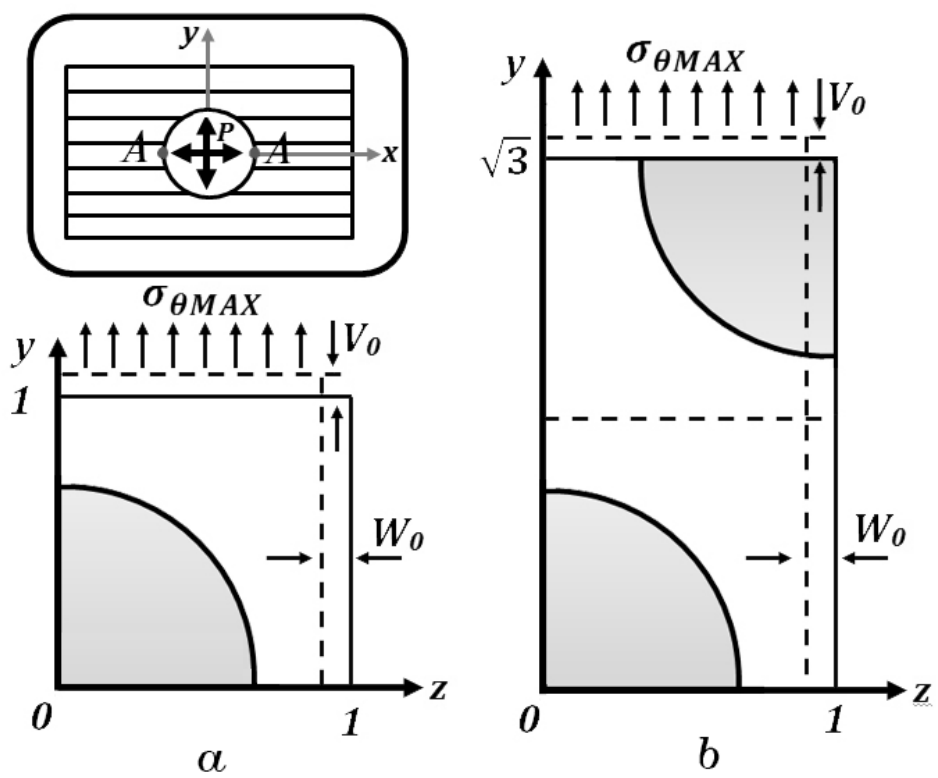

Figure 5. Representative cell model for $(a)$ square and $(b)$ hexagonal fiber arrangement

In this case, assuming an element is at point $A$ and uniform normal pressure $P$ and a stress, $\sigma_{\theta(\operatorname{Max})}$ was applied on it, while the change in the arrangement of the element is studied in both square and hexagonal arrangements (Fig. 5). The element is located on the edge of the plate at point $A$. Following the exerted pressure, $\sigma_{x}=P$ and stress, $\sigma_{y}=\sigma_{\theta(\text { Max })}$, given the arrangement of the plate, the line $y=1$ or $y=\sqrt{3}$ will decrease along the $y$-axis by $v_{0}$, while $z=1$ will increase along the $z$-axis by $w_{0}$.

While applying a uniform normal pressure on the contour of the circular hole, the conditions on the lines of representative cell should be established due to the symmetry and the boundary conditions:

on the lines $y=0: v_{0}=0$ and $z=0: w_{0}=0$; in the plane yoz: $-P$.

Subsequently, the boundary conditions are conditions of the periodicity of mechanical fields in view of the deformation:

On the lines $y=1, y=\sqrt{3}$ for the square arrangement and hexagonal arrangements:

$$
\left\langle\sigma_{y}\right\rangle=\int_{0}^{1} \sigma_{y} d z=\sigma_{\theta(\operatorname{Max})}
$$

On the line $z=1$ for the square arrangements:

$$
\left\langle\sigma_{z}\right\rangle=\int_{0}^{1} \sigma_{z} d y=0 .
$$

For hexagonal arrangements:

$$
\left\langle\sigma_{z}\right\rangle=\int_{0}^{\sqrt{3}} \sigma_{z} d y=0 .
$$

The micro-stress concentration $K_{(\text {micro })}$ caused by $\sigma_{\theta(\text { Max })}$ is obtained using:

$$
K_{(\text {Micro })}=\frac{\sigma_{(\text {Max })}^{\text {Mises }}}{\sigma_{\theta(\text { Max })}}
$$

The displacements on the lines of cell satisfy the boundary conditions (8), (9) and (10) on the cell for composite plate with square arrangement for $\xi=0.488$ while applying uniform normal pressure, 


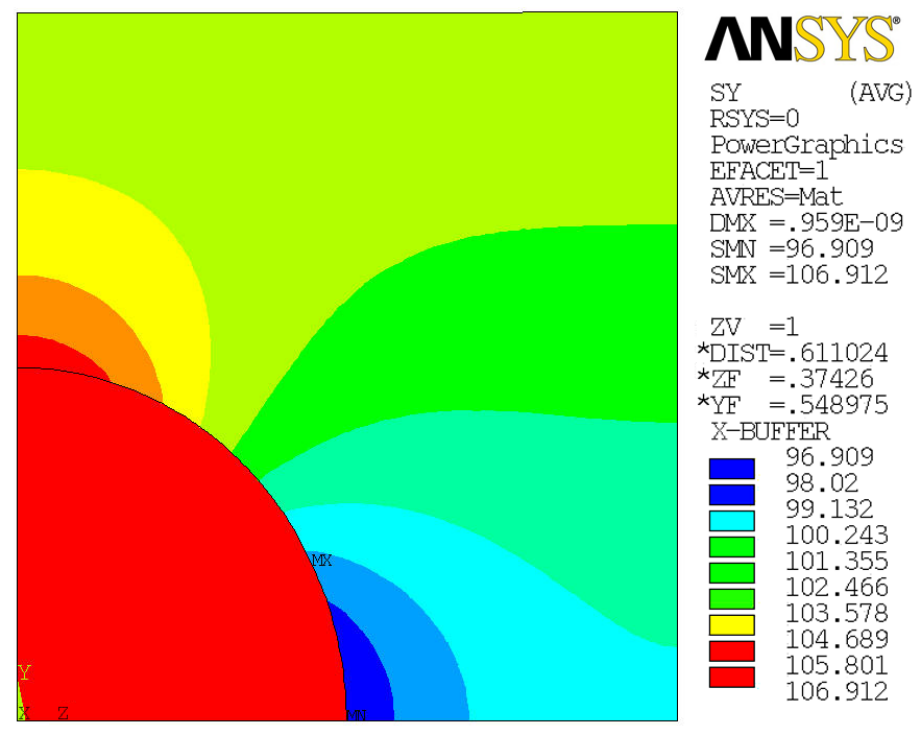

Figure 6. The normal stress $\sigma_{y}$ on the representative cell where $P=100$

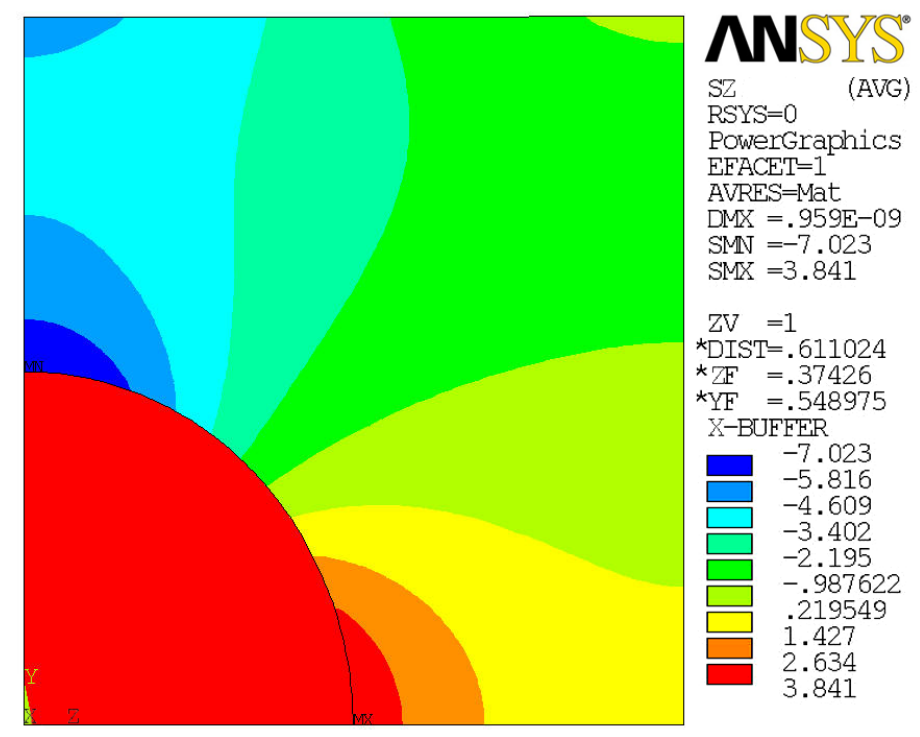

Figure 7. The normal stress $\sigma_{z}$ on the representative cell where $P=100$

$P=100$, on the boundary of the hole:

$$
\begin{cases}y=1: & v=-0.63 \cdot 10^{-9} \\ z=1: & w=0.724 \cdot 10^{-9}\end{cases}
$$

Figure 6 and Figure 7 shows the resultant normal stress $\sigma_{y}$, and the normal stress $\sigma_{x}$ on a cell using finite element method with the help of ANSYS.

Figure 8 shows the Mises stress on a cell consisting of the matrix-reinforcement for composite plate with a square arrangement.

Figure 9 shows the microstress concentration around of the circular hole versus $a$ for $b=1$ when applying uniform normal pressure on the edge of the hole by the finite elements method. Two charts for the orthotropic plates are given for both square and hexagonal arrangements.

The microstress concentration near the circular hole increased from 1 when the distance between the centers of the reinforcements was increased. On the other hand, the microstress concentration in the square arrangement is higher than the hexagonal arrangement. 

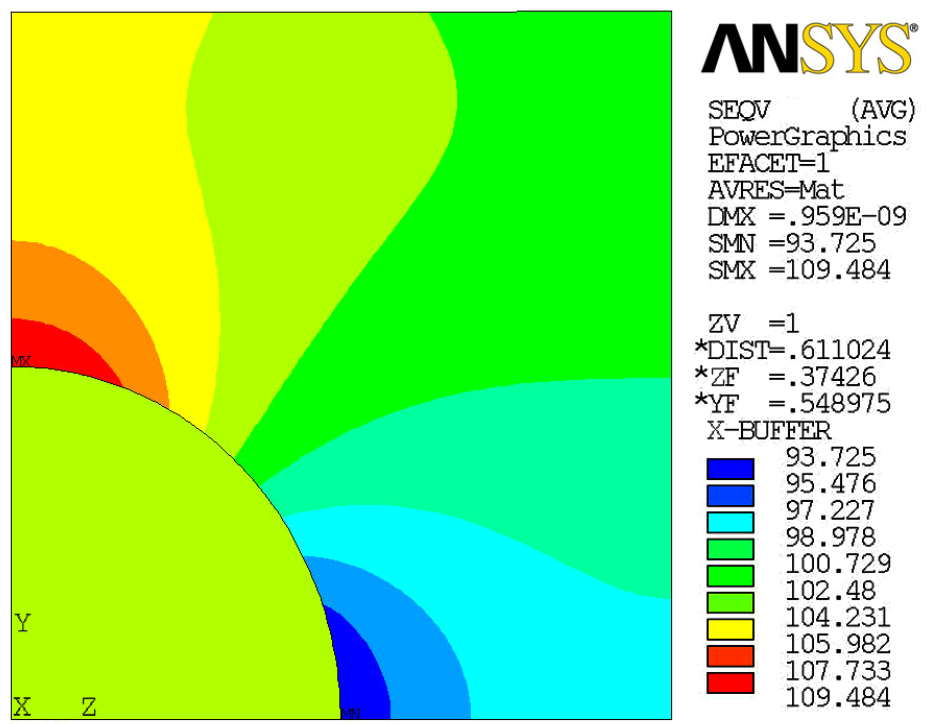

Figure 8. The Von Mises stress on the representative cell where $P=100$

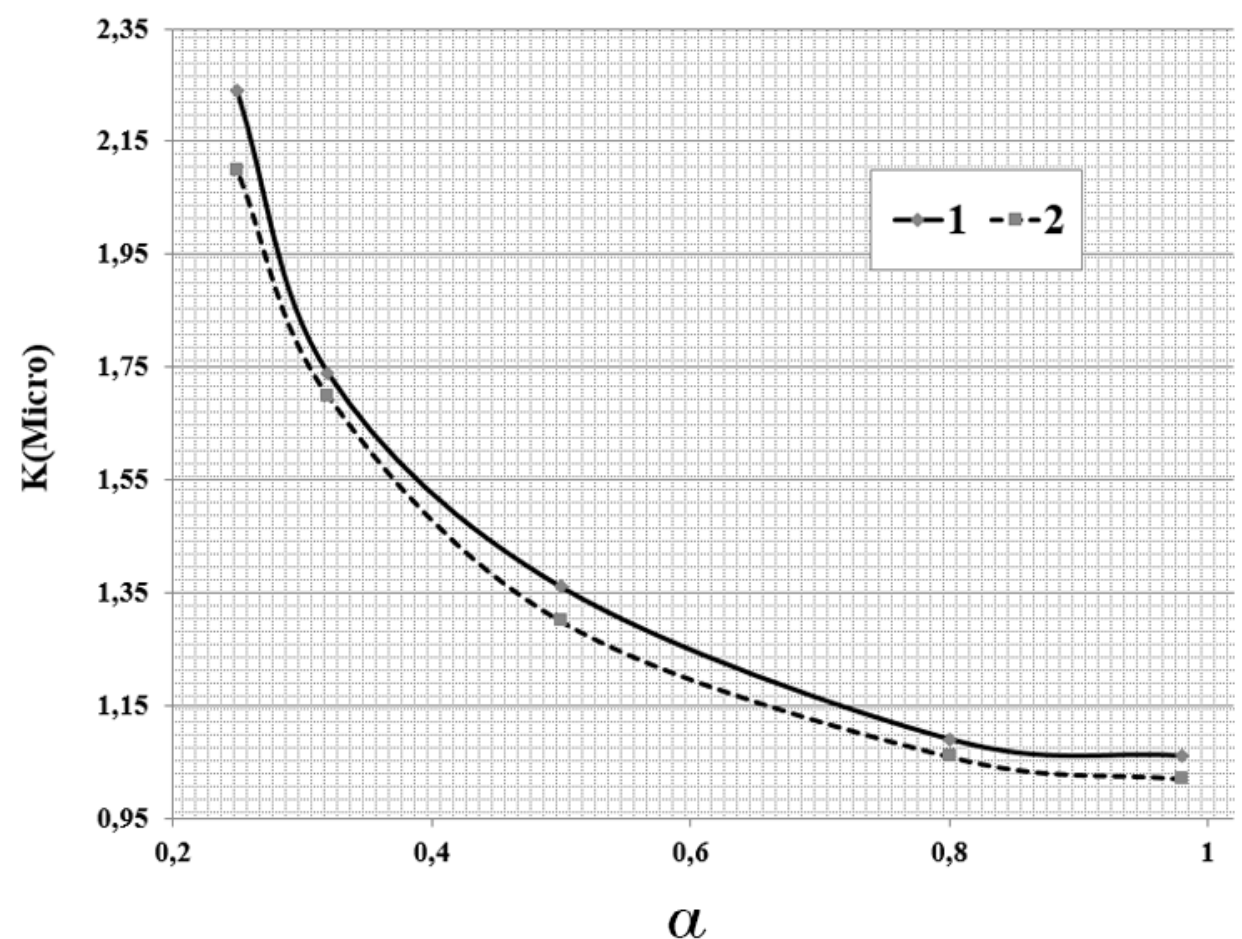

Figure 9. Microstress concentration around the circular hole as a function of radius $a$ 


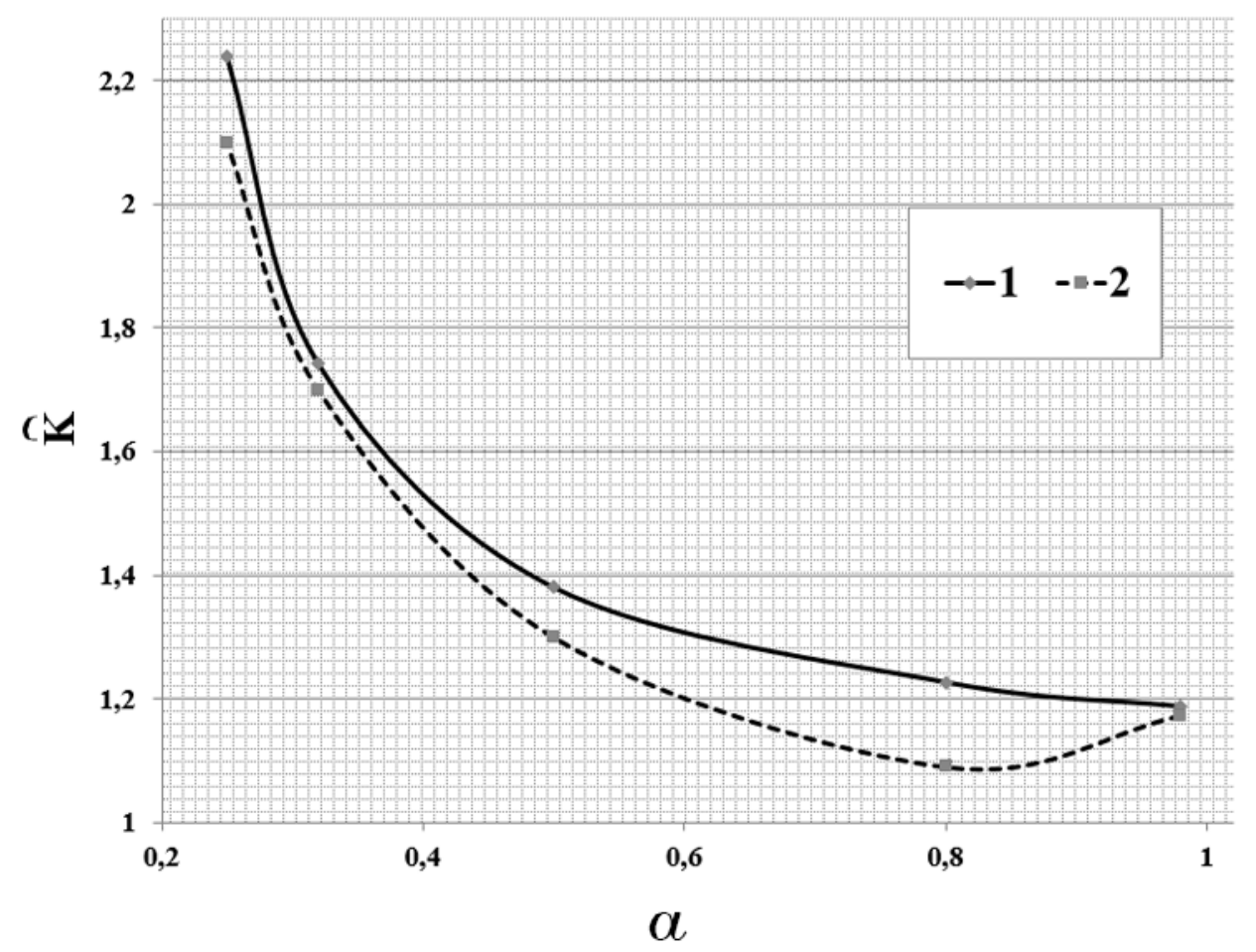

Figure 10. Total stress concentration around the circular hole as a function of radius $a$

\section{$\S 4$. Total stress concentration on the boundary of a circular hole in an orthotropic plate}

Macro- and microstress concentrations around of the circular hole in an orthotropic plate were investigated. The total stress concentration is the product of macro- and microstress concentrations. Thus, the total concentration is obtained using Eq. (6) and (11):

$$
\widehat{K}=K_{1} \cdot K_{(\text {Micro })}=\frac{\sigma_{(\text {Max })}^{\text {Mises }}}{P} .
$$

Figure 10 shows the total stress concentration while applying uniform normal pressure on the edge of the hole versus $a$ for $b=1$ in the case of by the finite elements method.

The total stress concentration, like the microstress, reduced when the radius of the reinforcement (or the volume ratio of the components) was increased. The total stress concentration is identical for both arrangements when the volume ration of the components is maximum.

The results of this research done on plate for the hydroxyapatite / titanium (biomaterial), confirmed the dependence of the results to the ratio, $\xi$, a character of the properties in these constituents.

In this research the proposed method is independent of the complex relationships and mathematical analysis, but dependent on the geometry of the structure.

\section{$\S 5$. Conclusion}

In this paper a new approach to the study of stress concentration in composite plates with circular holes is developed. The feature of the proposed approach is to analyze the stress concentration at two levels. The analysis of the concentration of macro level composite is, however, considered as a homogeneous orthotropic material. Analysis of microstress concentration is made at the level of the minimal repetitive structure of the composite. For square and hexagonal fiber reinforcement representative, cell is allocated and boundary conditions are formulated for simulating the stress state of the cell as part of a homogeneous material. 
Stress intensity in the most dangerous point is determined by the product of stress concentration factor of micro and macro levels.

Finally, the developed approach makes provision for the determination of the allowable load based on the actual distribution of stresses in thin-walled structural elements which are made of composite materials.

\section{REFERENCES}

1. Attaf B. Advances in composite materials for medicine and nanotechnology, India: InTech, 2011.

2. Arifin A., Sulong A., Muhamad N., Syarif J., Ramli M.I. Material processing of hydroxyapatite and titanium alloy $(\mathrm{HA} / \mathrm{Ti})$ composite as implant materials using powder metallurgy: A review, Materials $\&$ Design, 2014, vol. 55, pp. 165-175.

3. Kuroda K., Okido M. Hydroxyapatite coating of titanium implants using hydroprocessing and evaluation of their osteoconductivity, Bioinorganic Chemistry and Applications, 2012, Article ID 730693, 7 p. http://dx.doi.org/10.1155/2012/730693

4. Takashima H., Shibata Y., Kim T.Y., Miyazaki T. Hydroxyapatite coating on a titanium metal substrate by a discharging method in modified artificial body fluid, Int. J. Oral Maxillofac Implants, 2004, vol. 19, no. 1 , pp. 66-72.

5. Itoh S., Kikuchi M., Koyama Y., Takakuda K., Shinomiya K., Tanaka J. Development of an artificial vertebral body using a novel biomaterial, hydroxyapatite/collagen composite, Biomaterials, 2002, vol. 23, no. 19 , pp. 19-26.

6. Shibata Y., Takashima H., Yamamoto H. Functionally gradient bonelike hydroxyapatite coating on a titanium metal substrate created by a discharging method in HBSS without organic molecules, Int. J. Oral Maxillofac Implants, 2004, vol. 19, no. 2, pp. 77-83.

7. Tan X.W., Beuerman R.W., Shi Z.L., Neoh K.G., Tan D., Khor K.A., Mehta J.S. In vivo evaluation of titanium oxide and hydroxyapatite as an artificial cornea skirt, Materials in Medicine, 2012, vol. 23, no. 4, pp. 1063-1072.

8. Ishiwata K., Tawara K., Matsushita J. Characterization of hydroxyapatite containing of titanium hydride sintered body by nano size powder, Materials Science Forum, 2013, vol. 761, pp. 135-139.

9. Robert M.J. Mechanics of composite materials, USA: Taylor \& Francis, 1999.

10. Berbinau P., Soutis C. A new approach for solving mixed boundary value problems along holes in orthotropic plates, International Journal of Solid and Arrangements, 2001, vol. 38, no. 1, pp. 143-159.

11. Muskhelishvilii N. Some basic problems of the mathematical theory of elasticity, Leiden: Noordhoff, 1963.

12. Lekhnitskii S. Anisotropic plates, London: Gordon Breach, 1968.

13. Savin G. Stress concentration around holes, New York: Pergamon Press, 1961.

14. Vanin G.A Mikromekhanika kompozitsionnykh materialov (Micromechanics of composite materials) Kiev: Naukova Dumka, 1985 (in Russian).

15. Basov K.A. ANSYS spravochnik pol'zovatelya (ANSYS Manual), Moscow: DMK, 2005 (in Russian).

16. Jahed H., Noban M.R., Eshraghi M.A. ANSYS Finite Element, Iran: University Tehran, 2010 (in Persian).

17. Barbero E.J. Finite element analysis of composite materials, USA: CRC Press Tailor \& Group, 2008.

18. Matthews F.L., Davies D., Hitchings G.A.O., Soutis C. Finite element modeling of composite materials and structure, USA: CRC Press Tailor \& Group, 2008.

19. Pal B., Haseebuddin M.R. Analytical estimation of elastic properties of polypropylene fiber matrix composite by finite element, Advances in Materials Physics and Chemistry, 2012, vol. 2, no. 1, pp. 23-30.

20. Schmauder S., Mishnaevsky L. Micromechanics and nanosimulation of metals and composites, Springer, 2008.

21. Altenbach H., Fedorov V.A. Structural elastic and creep models of a UD composite in longitudinal shear, Mechanics of Composite Materials, 2007, vol. 43, no. 4, pp. 289-298.

22. Odegarda G.M., Pipesb R.B., Hubertc P. Comparison of two models of SWCN polymer composites, Composites Science and Technology, 2004, vol. 64, no. 7-8, pp. 1011-1020.

23. Whitney J.M., McCullough R.L. Micromechanical materials modeling. Delaware composites design encyclopedia, Basel: Technomic, Lancaster, 1990.

24. Fedorov V.A. Symmetry in a problem of transverse shear of unidirectional composites, Composites, Part B, 2014, vol. 56, pp. 263-269.

25. Nguyen D.D., Minh K. Bending analysis of three-phase polymer composite plates reinforced by glass fibers and titanium oxide particles, Computational Materials, 2010, vol. 49, no. 4, pp. 194-198. 
26. Andrianov I.V., Danishevs'kyy V.V., Guillet A., Pareige P. Effective properties and micro-mechanical response of filamentary composite wires under longitudinal shear, European Journal of Mechanics A/Solids, 2005, vol. 24, no. 2, pp. 195-206.

27. Lipatov Yu.S., Omanskii E.S. Kompozitnye materialy. Spravochnik (Composite materials. Handbook), Kiev: Naukova Dumka, 1985 (in Russian).

Received 12.02.2015

Darya zadeh Saeed, Post-Graduate Student, Department of Dynamics and Strength of Machines, National Technical University "Kharkiv Polytechnic Institute", ul. Frunze, 21, Kharkiv, 61002, Ukraine.

E-mail: saeed.daryazadeh@gmail.com

Lvov Gennadii Ivanovich, Doctor of Engineering, Professor, Head of Department of Dynamics and Strength of Machines, National Technical University "Kharkiv Polytechnic Institute", ul. Frunze, 21, Kharkiv, 61002, Ukraine.

E-mail: lvovgi@list.ru

\section{С. Дария заде, Г. И. Лввов \\ Анализ напряжений в бесконечной пластине из гидроксиапатита / титана с нагруженным круглым отверстием}

Ключевые слова: композит, однонаправленные волокна, численный метод, граничные условия, концентрация напряжений.

УДК 539.32

Цель существующего исследования - вычисление концентрации макро- и микронапряжений в армированный пластине из биоматериала с круглым отверстием в зависимости от коэффициента объемного содержания материалов. Были вычислены величины макро- и микронапряжений на контуре отверстия в зависимости от структуры пластинки. В этой статье напряжение вокруг отверстия было вычислено для ортотропной однонаправленно укрепленной волокном пластинки в зависимости от коэффициента объемного содержания материалов в соединении. Было вычислено распределение напряжений с использованием теоретического метода и метода конечных элементов. Граничные условия, установленные на контуре отверстия, - однородное нормальное давление. В этом исследовании был применен новый числовой метод для нахождения микронапряжений для сложных пластин с круглым отверстием, на контуре которого действует однородное нормальное давление. Результаты показывают макрои микронапряжения, вычисленные для двух различных структур, и поведение ортотропной пластинки с круглым отверстием. В этом исследовании использовался пакет ANSYS и конечно-элементная представительная модель пластинки.

\section{СПИСОК ЛИТЕРАТУРЫ}

1. Attaf B. Advances in composite materials for medicine and nanotechnology. India: InTech, 2011.

2. Arifina A., Sulong A., Muhamad N., Syarif J., Ramli M.I. Material processing of hydroxyapatite and titanium alloy $(\mathrm{HA} / \mathrm{Ti})$ composite as implant materials using powder metallurgy: A review // Materials \& Design. 2014. Vol. 55. P. 165-175.

3. Kuroda K., Okido M. Hydroxyapatite coating of titanium implants using hydroprocessing and evaluation of their osteoconductivity // Bioinorganic Chemistry and Applications. 2012. Article ID 730693.7 p.

4. Takashima H., Shibata Y., Kim T.Y., Miyazaki T. Hydroxyapatite coating on a titanium metal substrate by a discharging method in modified artificial body fluid // Int. J. Oral Maxillofac Implants. 2004. Vol. 19. № 1. P. 66-72.

5. Itoh S., Kikuchi M., Koyama Y., Takakuda K., Shinomiya K., Tanaka J. Development of an artificial vertebral body using a novel biomaterial, hydroxyapatite/collagen composite // Biomaterials. 2002. Vol. 23. № 19. P. 19-26.

6. Shibata Y., Takashima H., Yamamoto H. Functionally gradient bonelike hydroxyapatite coating on a titanium metal substrate created by a discharging method in HBSS without organic molecules // Int. J. Oral Maxillofac Implants. 2004. Vol. 19. № 2. P. 77-83. 
7. Tan X.W., Beuerman R.W., Shi Z.L., Neoh K.G., Tan D., Khor K.A., Mehta J.S. In vivo evaluation of titanium oxide and hydroxyapatite as an artificial cornea skirt // Materials in Medicine. 2012. Vol. 23. № 4. P. 63-72.

8. Ishiwata K., Tawara K., Matsushita J. Characterization of hydroxyapatite containing of titanium hydride sintered body by nano size роwdeк // Materials Science Forum. 2013. Vol. 761. P. 135-139.

9. Robert M.J. Mechanics of composite materials. USA: Taylor \& Francis, 1999.

10. Berbinau P., Soutis C. A new approach for solving mixed boundary value problems along holes in orthotropic plates // International Journal of Solid and Arrangements. 2001. Vol. 38. № 1. P. $143-159$.

11. Muskhelishvilii N. Some basic problems of the mathematical theory of elasticity. Leiden: Noordhoff, 1963.

12. Lekhnitskii S. Anisotropic plates. London: Gordon Breach, 1968.

13. Savin G. Stress concentration around holes. New York: Pergamon Press, 1961.

14. Ванин Г.А. Микромеханика композиционных материалов. Киев: Наукова думка, 1985.

15. Басов K.A. ANSYS. Справочник пользователя. M.: DMK, 2005.

16. Jahed H., Noban M.R., Eshraghi M.A. ANSYS finite element. Iran: University Tehran, 2010.

17. Barbero E.J. Finite element analysis of composite materials. USA: CRC Press Tailor \& Group, 2008.

18. Matthews F.L., Davies D., Hitchings G.A.O., Soutis C. Finite element modeling of composite materials and structure. USA: CRC Press Tailor \& Group, 2008.

19. Pal B., Haseebuddin M.R. Analytical estimation of elastic properties of polypropylene fiber matrix composite by finite element // Advances in Materials Physics and Chemistry. 2012. Vol. 2 . № 1 . P. 23-30.

20. Schmauder S., Mishnaevsky L. Micromechanics and nanosimulation of metals and composites. Springer, 2008. $420 \mathrm{p}$.

21. Альтенбах Х., Федоров В.А. Структурные модели упругости и ползучести однонаправленного композита при продольном сдвиге // Механика композитных материалов, 2007. Т. 43. № 4. С. 437-448.

22. Odegarda G.M., Pipesb R.B., Hubertc P. Comparison of two models of SWCN polymer composites // Composites Science and Technology. 2004. Vol. 64. № 7-8. P. 1011-1020.

23. Whitney J.M., McCullough R.L. Micromechanical materials modeling. Delaware composites design encyclopedia. Basel: Technomic, Lancaster, 1990.

24. Fedorov V.A. Symmetry in a problem of transverse shear of unidirectional composites // Composites. Part B. 2014. Vol. 56. P. 263-269.

25. Nguyen D.D., Minh K. Bending analysis of three-phase polymer composite plates reinforced by glass fibers and titanium oxide particles // Computational Materials. 2010. Vol. 49. № 4. P. 194-198.

26. Andrianov I.V., Danishevs'kyy V.V., Guillet A., Pareige P. Effective properties and micro- mechanical response of filamentary composite wires under longitudinal shear // European Journal of Mechanics A/Solids. 2005. Vol. 24. № 2. P. 195-206.

27. Липатов Ю.С., Оманский Е.С. Композитные материалы. Справочник. Киев: Наукова думка, 1985.

Поступила в редакцию 12.02 .2015

Дария заде Саид, аспирант, кафедра динамики и прочности машин, Национальный технический университет «Харьковский политехнический институт», ул. Фрунзе, 21, Харьков, 61002, Украина. E-mail: saeed.daryazadeh@gmail.com

Львов Геннадий Иванович, д. т.н., профессор, зав. кафедрой динамики и прочности машин, Национальный технический университет «Харьковский политехнический институт», ул. Фрунзе, 21, Харьков, 61002, Украина.

E-mail: lvovgi@list.ru 